УДК 338.432

DOI: https://doi.org/10.32851/2708-0366/2021.9.16

\begin{abstract}
Лобода O.M.
кандидат технічних наук, доцент,

Херсонський державний аграрно-економічний університет ORCID: https://orcid.org/0000-0001-9826-9443
\end{abstract}

Худік Н.Д.

старший викладач,

Херсонський державний аграрно-економічний університет ORCID: https://orcid.org/0000-0002-2310-799X

Loboda Olena, Khudik Natalya

Kherson State Agrarian and Economic University

\title{
ЗАСТОСУВАННЯ ІМІТАЦІЙНОЇ МОДЕЛІ СИСТЕМИ ПРИЙНЯТТЯ РІШЕНЬ НА ПІДПРИЄМСТВАХ МАЛОГО БІЗНЕСУ
}

\section{APPLICATION OF SIMULATION MODEL A DECISION-MAKING SYSTEM IN SMALL BUSINESS}

У статті показано, щз процес стратегічного управління на невеликому підприємстві неформалізований та найчастіше протікає в знанні керівника підприємства на тлі потоку інших завдань. Доведено, щзо актуальним завданням є створення інформаційної системи прийняття управлінських рішень, яка на основі планування фінансового стану малого підприємства могла би підказати керівнику, як грамотно розпоряджатися фінансовими засобами. Розроблено новий підхід до вирішення проблеми створення механізмів та інструментів засобів для підтримки процесу прийняття інвестиційних рішень у малому бізнесі на основі процедури ситуачійного аналізу ринку як складної соціально-економічної системи в умовах невизначеності. Розглянуто імітаційну модель системи управління як найбільш важливий елемент системи підтримки прийняття рішень, щзо визначає ефективність рішення. Дослідження проводиться на основі інтеграиії парадигми багатоагентних систем як моделі системи управління, які побудовані за допомогою індуктивних суджень агентів та інструментів нечіткого логічного висновку для обробки невизначеної інформації.

Ключові слова: інформачійні технологї, управлінські рішення, інтегрована система, моделювання, система управління, малий бізнес.

В статье показано, что прочесс стратегического управления на небольшом предприятии не формализован и чаще всего протекает в знаниях руководителя предприятия на фоне потока других задач. Доказано, что актуальная задача-создание информационной системь принятия управленческих решений, которая на основе планирования финансового состояния малого предприятия могла бы подсказать руководителю, как грамотно распоряжаться финансовыми средствами. Разработан новый подход к решению проблемы создания механизмов и инструментов средств для поддержки проиесса принятия инвестиционных решений в малом бизнесе на основе процедуры ситуационного анализа рынка как сложной социально-экономической системы в условиях неопределенности. Рассмотрена имитаиионная модель системь управления как наиболее важный элемент системь поддержки принятия решений, определяющий эффективность решения. Исследование проводится на основе интеграчии парадигмы многоагентных систем в качестве модели системы управления, построенных с помощью индуктивных суждений агентов и инструментов нечеткого логического вывода для обработки неопределенной информации.

Ключевые слова: информационные технологии, управленческие решения, интегрированная система, моделирование, система управления, мальй бизнес.

The article shows that the process of strategic management in a small enterprise is unformalized and most often proceeds in the knowledge of the head of the enterprise on the background of the flow of other tasks. It is proved that the actual task is to create an information system of management decisions, which on the basis of planning the financial condition of the small enterprise could advise 
the head of how to properly dispose of funds. A new approach to solve the problem of creating mechanisms and tools to support the investment decision-making process in small businesses based on the procedure of situational analysis of the market as a complex socio-economic system in conditions of uncertainty has been developed. The simulation model of the management system as the most important element of the decision support system, which determines the effectiveness of the decision. The study is based on the integration of the paradigm of multi-agent systems as a management system model, built with inductive judgments of agents and fuzzy logic inference tools for processing uncertain information. It is analyzed that within the framework of the creation of such information products it is reasonable to justify the use of some elements of the socialization of business processes to create applications that would be not only convenient and useful, that is, effective tools. In addition, based on the accumulation of data and data from statistical databases, the system should be able to conduct a summary analysis of the industry, which increases the decision-making tools for potential investors and managers. The presented approach increases the validity of applied management decisions based on the methodology of multi-agent programming, fuzzy logic inference procedure and decision-making under uncertainty. It is proved that the use of fuzzy logic methods of processing fuzzy information and the formation of fuzzy logical conclusions in the decision support system circuit can be considered promising for the evaluation of situational strategies and the development of effective management decisions.

Key words: information technologies, managerial decisions, integrated system, modelling, management system, small business.

Постановка проблеми. Нині одніми з найбільш затребуваних бізнес-структур галузі інформаційних технологій $є$ автоматизація управління підприємства, створення інформаційних систем для бізнесу. На ринку широко представлені та активно розвиваються такі класи інформаційних систем: ERP (корпоративні інформаційні системи), BMP (системи управління процесами), CRM (системи управління відносинами з клієнтами), HD (системи управління технічною підтримкою співробітників), HRM (системи управління персоналом) та ін. Більшу частину представників класу ERP-рішень відносять до так званих важких систем через широту класу завдань, що вирішуються, багату функціональність, високу вартість рішення та довгі терміни впровадження.

Але серед невеликих підприємств, які відносяться до так званого малого бізнесу та активно обробляють інформацію, також $є$ велика потреба в упорядкуванні та автоматизації інформаційних процесів, що протікають. Окрім цього, на ринку практично не представлено інформаційні системи для аналізу фінансового та господарського стану підприємства, які орієнтовані на малий бізнес, оскільки вони дуже затратні.

Прикладами компаній такого типу, зокрема, є невеликі організації, які поставляють товари або надають професійні послуги (комп'ютерні магазини, постачальники мережного та комунікаційного обладнання, вебстудії, рекламні агентства), консультативні компанії (юридичні, експертні), компанії перекладу та копірайт-агентства.

Від'ємними рисами таких компаній є: значна роль інформаційних процесів в управлінні компанією та різноманіття видів даних, які підлягають збереженню та обліку; невелика кількість співробітників; обмежене число рівнів управління процесами та їх учасників; невисока складність бізнес-процесів; простота бухгалтерського обліку; активне використання надомної праці та технології мобільного офісу.

Наше дослідження показує, що аналітичні системи застосовують, головним чином, середні та великі підприємства. Причина, через яку малі підприємства не заінтересовані у використанні аналітичних інструментів, достатньо очевидна. Процес стратегічного управління на невеликому підприємстві неформалізований та взагалі не визначений як особливе завдання. Він найчастіше протікає у знанні керівника підприємства на тлі потоку інших завдань та не ідентифікується як такий, що потребує спеціальної уваги. Іншими словами, у малого підприємства на стратегічне управління взагалі немає ресурсів. При цьому єдина стратегія для більшості з них - це стратегія виживання.

Особливо мало створюється інформаційних систем для малого бізнесу. Велика кількість малих підприємств у нашій країні закривається через невміле управління, нечіткий розподіл та використання доходів, ризикове інвестування. 
Виходячи з вищесказаного, можна стверджувати, що актуальним завданням $є$ створення інформаційної системи, яка на основі планування фінансового стану малого підприємства могла би підказати керівнику, як грамотно розпоряджатися фінансовими засобами. Необхідно допомогти власнику малого підприємства вирішувати такі питання: реалізація прибутку або виведення його з бізнесу; реалізація вибору між ціною, якістю або низькими витратами; знаходження оптимального обсягу взаємного фінансування; визначення оптимального співвідношення між коштами інвестора та довгостроковим інвестуванням та ін.

Керівник малого підприємства найчастіше не може собі цього дозволити. Сам же керівник найчастіше $є$ спеціалістом тільки в технології виробництва своїх товарів та послуг. Такий стан справ потребує побудови інтелектуальних систем обробки та оцінки рішень, що приймаються, - систем підтримки прийняття рішень.

Причому модель системи управління є найбільш важливим елементом системи підтримки прийняття рішень та визначає ефективність рішення. Це дослідження проводиться на основі інтеграції парадигми багатоагентних систем як моделі системи управління, що побудовані на основі індуктивних суджень агентів та інструментів нечіткого логічного висновку для обробки невизначеної інформації.

Аналіз останніх досліджень і публікацій. Використовуючи теорію ситуаційного управління в роботах Б.С. Грабовецького, Г.М. Гнатієнко, В.С. Снитюка, можливо представити простір початкових, поточних та цільових станів компонентів процесів функціонування малого бізнесу. Планування та використання рішень зазвичай уявляють за допомогою теорії графів та методологій управлінських рішень [1, с. 26]. Фреймова теорія дає змогу представити стереотипні ситуації в структурі малого бізнесу в процесі інвестування, а також варіювати структурою таких моделей шляхом фреймових трансформацій. Стереотипні ситуації можливо поєднати в реальні процеси за допомогою фреймових мереж. Процедурні компоненти фреймів забезпечують ефективність таких моделей. Нечітко визначені атрибути та процеси, без яких важко обійтися під час моделювання функціонування об'єктів малого бізнесу, зазвичай уявляють у теорії нечітких множин та нечіткої логіки В.К. Збарського, В.І. Мацибори, В.В. Марасанова, А.А. Чалого. Темпоральна логіка необхідна для опису часової послідовності та пояснення результатів логічного висновку. Такі системи найчистіше підходять для побудови експертних компонентів механізму пошуку рішень [6, с. 104].

Вибір тієї або іншої з перерахованих вище моделей представлення знань або нової інтегрованої моделі, яка заснована на поєднанні моделей різних типів, повинен проводитися на основі детального вивчення предметної сфери управління інвестиціями в малому бізнесі та опитування спеціалістів-експертів [1, с. 58]. На основі формування конкретних моделей представлення знань необхідно реалізувати принципи та вибирати засоби створення СППР, які дають можливість вирішувати завдання за допомогою логічного виводу та здобувати надійні результати [2, с. 34]. Передбачається, що такі інтелектуальні системи повинні мати доступ до системи фактів, які називаються базами знань, та будуть доводити висновки з інформації, що міститься у цих базах знань [4].

Формулювання цілей статті. Розробити новий підхід для вирішення проблеми створення механізмів та інструментів засобів для підтримки процесу прийняття інвестиційних рішень у малому бізнесі на основі процедури ситуаційного аналізу ринку як складної соціально-економічної системи в умовах невизначеності.

Виклад основного матеріалу. Інформаційна система повинна бути не лише «фінансовим калькулятором», а й виконувати роль помічника-експерта, причому під час розроблення такої системи необхідно використовувати методи та моделі штучного інтелекту Окрім цього, така система повинна бути доступною користувачам за вартістю та запропонованим сервісом. 
Особлива велике значення має даний аналіз у сфері малих та середніх підприємств, у яких найчастіше не існує вільних коштів та для яких ціна рішення дуже велика $[3$, c. 86]. Сьогодні на ринку програмних засобів представлено декілька рішень у сфері аналізу фінансової діяльності підприємства, але вони мають істотні недоліки: вони розраховані на застосування на робочих місцях менеджера та ліцензуються на робоче місце та комп'ютер; вони не дають змоги порівнювати здобуті результати з іншими фірмами галузі або сфери; найчастіше вони не розраховані на малі фірми.

Ефективна інформаційна підтримка прийняття інвестиційних рішень у малому бізнесі потребує реалізації нових підходів та нових вимог до програмних продуктів. Будемо виділяти такі основні проблеми організації фінансового планування у малих підприємствах: відсутність системи бухгалтерського обліку та звітності; відсутність у керівників малих підприємств необхідного мінімуму знань у сфері фінансового менеджменту; складність програмних засобів, що маються в аспекті представлення вихідної інформації; відсутність наочності та простоти висновків щодо фінансового стану підприємства; відсутність простих програмних засобів для фінансового планування, які не потребують спеціальної освітньої підготовки менеджера та спеціальної підготовки користувача, великих фінансових вкладень, великого обсягу вхідної інформації, високої складності вхідної інформації; наявність завищених вимог до захищеності програмних засобів у зв'язку з рейдерством, тіньовим оборотом, відхиленням від податків та ін.; нестійкість економічних умов господарювання для малого бізнесу, що веде до планування короткостроковості існування підприємств; відсутність потреб вкладення коштів у бізнес і формування уявлення про необхідність виводу залучених засобів із бізнесу тощо.

Розроблення програмного продукту нового рівня на основі сучасних інформаційних технологій: хмарних, соціальних мереж, ігрових механік та проведення міждисциплінарних наукових досліджень припускає розвиток програмних засобів такого рівня на основі методів штучного інтелекту, що $є$ актуальним науковим завданням. На нашу думку, вирішення цього завдання, тобто розроблення системи фінансового планування та аналізу діяльності для малого підприємства, полягає у пропозиції змінювати парадигму процесу впровадження інформаційних технологій у бізнес-процеси. Останні роки інформаційні технології для бізнесу розумілись як стандартний набір засобів автоматизації бізнес-процесів організації: інфраструктура, бухгалтерія, склад, CRM-система.

На сучасному етапі розвитку інформаційних технологій виникла необхідність відмовитися від стандартного процесу автоматизації та перейти до процесу соціальної інформатизації бізнесу. Звичайні процеси автоматизації потребують стаціонарного комп'ютера, аналітика, бухгалтера та масу часу. Наступив час сумісної інформатизації праці керівника фірми. Необхідно перенести аналітичне робоче місце на мобільну платформу та дати можливість менеджеру використовувати необхідні йому інструменти в будь-який момент часу та в різних місцях. Керівники малих підприємств не схильні брати на роботу економістів-аналітиків. Вони вимушені самостійно приймати важливі фінансові рішення, при цьому самі не мають поглиблених знань економіки та математики, не дуже розбираються у високих технологіях та не будуть використовувати інформацію, якщо вона не представлена в доступній формі. Економістам-аналітикам потребується одні інструменти, особам, що приймають рішення, - інші. Сьогодні можливо говорити про затребуваність нового класу інформаційних систем бізнес-аналітики для широкого застосування не лише для професіоналів - достатньо потужних, але водночас простих у використанні. Тобто обчислювання мають такі характеристики: більш істотна та звична взаємодія особи, що приймає рішення 3 комп'ютерними технологіями в актуальному контексті; інтеграція комп'ютерних розрахунків у навколишнє середовище. 
Передбачається перейти від складних для інтерпретації економічних даних до показників фінансової стійкості. Такий комплексний показник, що виражається лінгвістично і відповідає іiі нечіткими оцінками, можливо в реальному часі транслювати користувачу у вигляді доступних та очевидних образів, використовує здатність сприймати інформацію $з$ першого погляду без додаткового когнітивного навантаження. Наявність вебінтерфейсу та (або) мобільного рішення дасть змогу контролювати стан без прив'язки до робочого місця та здобувати сучасний сигнал до дії.

У рамках створення таких інформаційних продуктів доцільно обгрунтувати використання деяких елементів соціалізації бізнес-процесів для створення додатків, які були б не лише зручними та корисними, тобто ефективними інструментами. Окрім цього, на основі накопичення даних і даних статистичних баз даних система повинна мати можливість проводити зведений аналіз по галузі, що збільшує засоби для прийняття рішень потенціальним інвесторам та менеджерам. Такий стан речей у предметній сфері, інформатизації малого бізнесу висуває низку вимог до програмного, апаратного та організаційного забезпечення системи підтримки прийняття управлінських рішень. Імовірна відсутність у керівника малого бізнесу знань та навиків для аналізу ситуації, яка представлена у вигляді таблиць та звітів, з одного боку, потребує створення налаштованого експертно-аналітичного шару СППР. 3 іншого боку, цей шар не повинен скривати звітність від керівника та повинен посилювати здатність до поглибленого вивчення. Звідси витікає наявність таких компонентів СППР, як засоби автоматизації аналізу даних, експертних та відповідних моделей із розширеними функціями пояснення ситуації та запропонованих рішень. Важливо також уявляти можливість користувачу суміщати представлені дані та знання про ситуацію різного ступеня спільності. Особливу увагу слід звернути на форми представлення даних та рішень, простоту, доступність, забезпечення емоційної відповідності сприйняття ситуації керівником та складність ситуації.

Виконання потреб забезпечення поточної масштабованості та доступності додатків на багатьох доступних стаціонарних і мобільних пристроях повинно бути забезпечене на інформаційному, програмному та методичному рівнях. Важливою вимогою до СППР для малого бізнесу є дотримання конфіденційності даних та рішень, що приймаються. Для рівня малого підприємства зустрічається нагадування вузькоспеціалізованих відповідних систем, наприклад для формування цінової політики конкретного підприємства, вибору місця розміщення торгових точок і т. п.

Для кожного рівня СППР необхідні компоненти, моделі та методи, що представлені на рис. 1.

У процесі створення СППР повинно бути вирішено два завдання: завдання вилучення знань експертів, для вирішення якого потребується вибір кваліфікованих експертів, та завдання формалізації знань експертів із залученням спеціалістів у сфері формалізації знань експертів та створення моделей представлення знань.

Будемо розглядати функціонування малого підприємства на ринку з невеликою кількістю конкуруючих підприємств, які задовольняють частку ринкового попиту на продукцію широкого спектра та борються за максимальний прибуток, а також збереження частки ринку. Поведінка кожного підприємства зумовлюється вибраною стратегією ціноутворення, обсягами випуску продукції та досягненням інших цілей залежно від стану та стратегії всіх учасників ринку з визначенням компромісних рішень, які спрямовані на захоплення, утримання та стабілізацію ринку в умовах конкурентної боротьби. Покупці у своїх перевагах неоднорідні, що відображається множиною точок в n-мірному просторі опису продукту. Продавці характеризується власними функціями витрат та вибором альтернатив. Показники попиту покупців залежать від характеру, обсягу пропозицій і маркетингової політики, виду та цінності продукту, соціального капіталу.

Кожен з учасників ринку в змозі обмежити можливості конкурента своїм управлінським рішенням, впливає на умови обороту товарів на ринку. Управлінське рішення 
відноситься до вибору вартості, організації рекламної діяльності, формування властивості продукту та інших аспектів.

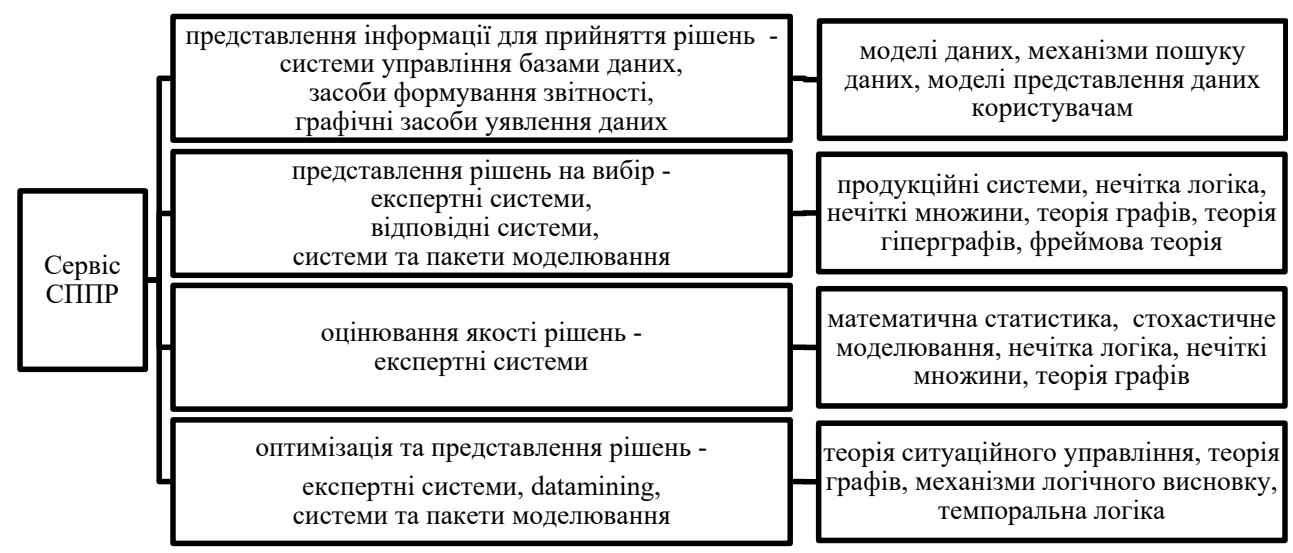

Рис. 1. Компоненти моделі та методи рівнів

Динаміка поведінки продавців та покупців на ринку неоднозначна, його стан неможливо спрогнозувати ні аналітичними методами, ні шляхом логічного аналізу в умовах невизначеності, нечіткої або неповної інформації. Стан ринку є результатом складної багатокрокової діяльності великого числа його активних учасників, а сам ринок являє собою приклад складної соціально-економічної системи, яка взаємодіє 3 навколишнім середовищем.

Для формалізованого опису діяльності покупців та продавців, які є активними учасниками на ринку, пропонується використовувати методологію багатоагентного програмування для ситуаційної моделі функціонування ринку як складної соціально-економічної системи. Її активними елементами є агенти-продавці та агенти-покупці, а також зовнішні факторні агенти, до яких відносяться ринкова ситуація та навколишнє соціально-економічне середовище. За такого підходу багатоагентна модель функціонування ринку може бути представлена у вигляді узагальненого кортежу фреймів як спеціальних моделей представлення знань:

$$
M=<A g, \operatorname{Mar}_{c h} ; A m b>,
$$

де $A g$ - учасники ринка; $M a r_{c h}$ - характеристика ринкових ситуацій; $A m b$ - характеристики зовнішнього соціально-економічного середовища для ринку.

Кожен фрейм являє собою складну семантичну структуру що відображає змістовий опис у структурно-класифікованій формі ієрархічних знань про будь-яке поняття соціально-економічної, технологічної або технічної системи. Фрейм будь-якого поняття складається із сукупності видалених блоків - питань, що відображають визначену властивість цього поняття, та блоків відповідей, що відображають різноманітні характеристики проявлення цієї властивості.

Розглянемо формальне відображення блоків змінних для кожного фрейму, що входять у кортеж (1):

1. $A g=\left\{A g_{1}, \ldots A g_{n}\right\}$, де значення блоків-змінних відповідне позиції економічних агентів на ринку, характеристика економічних агентів, характеристика конкуруючих видів продукції та стратегія економічних агентів;

2. $\operatorname{Mar}_{c h}=\operatorname{Mar} \operatorname{ch}\left(p, s, p_{s}, r, t, d\right)$, де значення блоків-змінних $\mathrm{p}$ - ступінь розвитку ринку; $\mathrm{s}$ - поточний обсяг ринку; $p_{s}$ - потенційний обсяг ринку; $r$ - оцінка темпів росту за період повного циклу продукту; $t$ - тенденції розвитку ринку; $d$ - канали збуту. 
3. $A m b=A m b\left(s_{l}, l_{e}\right)$, де значення блоків-змінних $s_{l}$ - рівень життя населення області, $l_{e}$ - рівень економічного розвитку області.

Функціонування ринку відображається моделлю (1) та є результатом багатокрокової ситуаційної взаємодії багатьох активних агентів суб'єктів ринку в умовах ринкової ситуації під впливом зовнішнього середовища. Ринкову ситуацію, або динаміку ринку, можливо задати через кінцеве число правил, що приводять ринок у визначений стан. Наприклад, агенти-продавці повинні самостійно приймати рішення про вартість, рекламу, властивості продукту, рівні запасів продукту, що утворюються за допомогою імітаційної моделі.

Імітація процедур прийняття рішень кожним активним агентом переводиться на кожному кроці ситуаційного моделювання 3 подальшим зміненням стану багатоагентної моделі. Кожній змінній стану відповідає раціональне управлінське рішення у вигляді деякого продукційного правила, яке зберігається в базі знань, що представлена в кодованому вигляді. Процедура прийняття рішень виробляє одне або декілька раціональних рішень для кожного активного агента на заданий період часу з варіюванням ціни, ринкової пропозиції продукту та нецінових факторів залежно від умовних подій та значень блоків параметрів фреймів, використовує базу знань продукційних правил за допомогою формальної операції перетину множин. Із декількох варіантів рішень вибирається оптимальне за критерієм максимуму прибутку для кожного агента-продавця в період, що розглядається.

У прикладі, що розглядається, ринок знаходиться на стадії розвитку, позиція агента-продавця на ринку оцінюється як середня, рівень життя населення області - як низький, раціональне рішення означає збереження обсягу випуску продукції та проведення заходів зі зниження собівартості продукції для активного агента-продавця, відносно якого проводиться прийняття рішення.

Після вироблення рішення для кожного активного агента-продавця проводиться оцінка всіх рішень і з урахуванням чинника конкуренції приймається рішення для свого підприємства. Дії, що пов'язані зі співробітництвом та конкуренцією у системі, реалізуються одночасно. Потім слід реалізувати дії одного або декількох активних агентів (транзакція), що відповідатиме новій точці відрахування на тимчасовий шкалі. У результаті реалізації дії ситуація на ринку змінюється, тому змінюється і значення частини блок-змінних. Відносно всіх прийнятих рішень агентів-продавців проводиться аналіз рішення та виявлення агента-переможця, на цій основі проводиться оновлення бази знань продукційних правил прийняття раціональних рішень.

Таким чином, для прийняття управлінських рішень підприємства малого бізнесу запропоновано метод імітаційного багатоагентного програмування, що дає змогу проводити ситуаційне моделювання функціонування ринку як складної соціально-економічної системи, активними елементами-суб'єктами якої є активні агенти-продавці, агенти-покупці та зовнішні факторні агенти, а також ринкова ситуація і навколишнє соціально-економічне середовище.

Вихідні змінні моделі $(У)$ прийняття управлінських рішень підприємства включають такі дані, як обсяг випуску продукції, ціна, витрати на рекламу та просування продаж, витрати на організації збуту, якість продукції. Цей перелік фіксований, тоді як вибір вхідних змінних $(X)$ є результатом експертного рішення компанії на основі знання ринкового середовища ведення свого бізнесу. Припустимо, підприємство аналізує вхідні змінні, що визначають управлінські рішення.

Дані підприємства: $X_{1}$ - обсяг продажів попереднього періоду; $X_{2}$ - прогноз продажів; $X_{3}$ - планові продажі; $X_{4}$ - цільовий прибуток; $X_{5}$ - ступінь задоволеності кліснтів. Дані агентів-конкурентів: $X_{6}$ - ціни; $X_{7}$ - якість продукції; $X_{8}$ - реклама; $X_{9}$ - витрати на маркетинг; $X_{10}$ - конкурентний рівень. Дані ринку: $X_{11}$ - обсяг ринку; $X_{12}$ - сегментація ринку. 
Такі змінні, як прогноз продаж, дані конкурентів, реклама, розподіл витрат та ін., $\epsilon$ невизначеним змінними, значення яких не може бути визначено точно. Але вони можуть бути інтерпретовані як високий, низький, пов'язаний із центром або середнім значенням. Аналогічно не може бути визначена точно змінна, що відображає граничну реакцію ринка, оскільки вона основана на оцінці або екстраполяції недостовірних даних. Суб'єктивні чинники, такі як конкуренція та конкурентні позиції підприємства, для яких якісна оцінка основана на чистому судженні експертів компанії та, як наслідок, людських суджень, слід розглядати як невизначені.

Тому, ураховуючи значну невизначеність інформації про конкурентну ситуацію на ринку та зовнішнє соціально-економічне середовище, необхідно формалізувати предметну сферу, а саме ситуацію на ринку, конкуруючі фірми-агенти, відношення між ними та раціональні рішення з використанням апарату теорії нечітких множин на основі імітаційного апарату. Передбачається, що будь-яку ситуацію або подію на ринку можна уявити нечіткою множиною, а будь-яка подія має тип та нечіткий зміст - сукупність нечітких множин, що відображають класифікацію подій. Для обробки невизначеної інформації та процедури прийняття рішень використовуються методи нечіткого логічного висновку та прийняття рішень в умовах невизначеності. Реалізація нечіткого висновку виконана з використанням алгоритму, в якому взаємозв'язок між заданими у вигляді нечітких множин входами $X=\left(X_{1}, X_{2}, \ldots X_{n}\right)$ i виходами Ү визначається нечіткою імплікацією.

$$
{ }_{p=1 i=1}^{k_{j}} n_{i}\left(X_{i}=a_{i, j p}\right) \rightarrow Y=d_{j}, j=\overline{1, m}
$$

де $a_{i, j p}$ - нечіткій терм, яким оцінюється лінгвістична змінна $X_{i}$ в рядку з номером $j p(p=1, \ldots, k) ; k$ - кількість рядків-кон'юкцій, у яких вихід - лінгвістична змінна $Y$ оцінюється термом $d ; m$ - кількість термів, які використовують для вихідної лінгвістичної змінної $Y$.

$$
\begin{gathered}
a_{i, j p}=\int_{X_{1}}^{X_{i}} \frac{\mu_{j p}\left(X_{i}\right)}{X_{i}}, X_{i} \in\left[X_{i}, \overline{X_{1}}\right] ; \\
d_{j}=\int_{\underline{Y}}^{\bar{Y}} \frac{\mu_{d_{j}}(Y)}{Y}, Y \in[\underline{Y}, \overline{\bar{Y}}],
\end{gathered}
$$

де $\mu_{j p}\left(X_{i}\right)$ та $\mu_{d_{j}}(Y)$ - функції приналежності входу $X_{i}$ та виходу $Y$ нечіткому терму.

Система нечіткого моделювання, як і будь-який інший тип моделювання, потребує калібрування шляхом удосконалення бази знань та підбору функцій приналежності. Комплексна процедура ситуаційного аналізу ринку як складної соціально-економічної системи в умовах невизначеності включає такі основні етапи: моніторинг зовнішнього та внутрішнього середовища; аналіз та обробка аналітичної, ймовірнісної і нечіткої інформації про стан ринку; аналітичний ситуаційний аналіз функціонування багатоагентної моделі ринку; вибір оптимальних маркетингових стратегій згідно з попитом на продукцію та пропозиціями продукції на ринку в поточних та майбутніх умовах; вибір оптимальних рішень; налаштування бази знань; підготовка звітних матеріалів за результатами обчислювального експерименту.

Процедура дає можливість аналізувати дані, які представлені у вербальній формі, 3 подальшим розробленням стратегій управління для багатоагентного конкурентного ринку за трьома налаштованими групами факторів, включаючи характеристики ринку, учасників ринку, соціально-економічне середовище. Процедура оцінювання параметрів управління на час стратегічного планування має обернений зв'язок, даючи змогу уточнювати базу знань та правила прийняття рішень. При цьому час планування відповідає часу оновлення продукту на ринку. 
У перспективі буде можлива реалізація СППР для комп'ютера, яка керуватиме знаннями в заданій предметній сфері з метою розроблення рекомендацій для керівників малого підприємства, та така програма гратиме роль асистента для особи, що приймає рішення.

Висновки. У роботі запропоновано комплексну процедуру ситуаційного аналізу ринку як складної соціально-економічної системи в умовах невизначеності. Процедура використовує як основу імітаційну багатоагентну нечітко-логічну модель прийняття рішень малими підприємствами. У моделі застосовуються методологія багатоагентного програмування, процедура нечіткого логічного висновку та прийняття рішень в умовах невизначеності. Запропонований підхід підвищує обгрунтування застосованих управлінських рішень. Багатоагентну модель використання нечітких логічних методів для обробки нечіткої інформації та формування нечітких логічних висновків у контурі системи підтримки прийняття рішень можна вважати перспективними для оцінки ситуаційних стратегій та розроблення ефективних управлінських рішень, ураховуючи попит і пропозиції в умовах багатоагентного ринку. Таким чином, процес створення та впровадження інформаційних систем на основі соціальної інформатизації бізнесу передбачає розроблення інтелектуальної аналітичної платформи розвитку відповідних систем як систем інформаційного супроводження та підтримки прийняття рішень в інвестиційних та виробничих бізнес-процесах, що виводять інформатизацію на більш високий інтелектуальний рівень.

\section{Список використаних джерел:}

1. Гнатієнко Г.М., Снитюк В.С. Експертні технології прийняття рішень : монографія. Київ : Маклаут, 2008. 444 c.

2. Грабовецький Б.Є. Методи експертних оцінок: теорія, методологія, напрямки використання : монографія. Вінниця : ВНТУ, 2010. $171 \mathrm{c.}$

3. Збарський В.К., Мацибора В.І. Економіка сільського господарства : навчальний посібник. Київ : Каравела, 2009. 264 с.

4. Лобода О.М. Застосування імітаційного моделювання та програмних комплексів при реалізації інноваційних проєктів в економічних системах. Ефективна економіка. 2020. № 11.

5. Лобода О.М. Вирішення задачі ідентифікації структури управління підприємством. Сучасна спеціальна техніка. 2012. № 3. С. 64-68.

6. Марасанов В.В., Пляшкевич О.М. Основи теорії проектування і оптимізації макроекономічних систем. Херсон : Айлант, 2002. 190 с.

\section{References:}

1. Hnatienko H.M., Snytiuk V.Ye. (2008) Ekspertni tekhnolohii pryiniattia rishen [Expert decision-making technologies]. Kyiv: TOV "Maklaut". (in Ukrainian)

2. Hrabovetskyi B.Ye. (2010) Metody ekspertnykh otsinok: teoriia, metodolohiia, napriamky vykorystannia [Methods of expert assessments: theory, methodology, areas of use]. Vinnitsa: VNTU. (in Ukrainian)

3. Zbarskyi V.K., Matsybora V.I. (2009) Ekonomika silskoho hospodarstva: navch. posibnyk [Agricultural economics: a textbook]. Kyiv: Karavela. (in Ukrainian)

4. Loboda O.M. (2020) Zastosuvannia imitatsiinoho modeliuvannia ta prohramnykh kompleksiv pry realizatsii innovatsiinykh proektiv $\mathrm{v}$ ekonomichnykh systemakh [Application of simulation modeling and software complexes in the implementation of innovative projects in economic systems]. Efektyvna ekonomika [Efficient economy] (electronic journal), vol. 11. Available at: http://www.economy.nayka.com.ua/?op=1\&z=8321 (accessed 15 October 2021).

5. Loboda O.M. (2012) Vyrishennia zadachi identyfikatsii struktury upravlinnia pidpryiemstva [Solving the problem of identifying the management structure of the enterprise]. Modern special equipment, vol. 3, pp. 64-68.

6. Marasanov V.V., Pliashkevych O.M. (2002) Osnovy teorii proektuvannia i optymizatsii makroekonomichnykh system [Fundamentals of the theory of design and optimization of macroeconomic systems]. Kherson: Ailant, p. 190. 